\title{
DNA 催化水相体系中的二硫缩醛反应
}

\author{
王长号李英豪贾国卿卢胜梅刘䶭李灿* \\ (催化基础国家重点实验室 中国科学院大连化学物理研究所 大连 116023)
}

\begin{abstract}
摘要 在各种生命起源假说中, 比较公认的是原生生命起源于 RNA. 在 RNA 世界中, RNA 不仅是遗传物质, 并且是具 有酶活性的催化剂. DNA 在自然界中普遍以双螺旋结构存在, 一直被认为只是生命体遗传信息的载体, 但是 DNA 和 RNA 相似的化学组成引发了研究者探究 DNA 是否具有催化功能. 尽管到目前为止在自然界还没有发现具有催化活性 的 DNA, 研究者利用有机反应模型已经开展研究 DNA 的相关催化功能, 例如利用 DNA 为模板进行有机合成和利用 DNA 的手性结构进行手性合成. 但是, 直接利用 DNA 作为催化剂进行有机反应的研究还不多见. 本文报道了源于鲱鱼 精的双链 DNA 可以催化水相体系中一系列醛的二硫缩醛反应. 通过实验推断 DNA 中的磷酸基团为主要的催化活性中 心, 并且 DNA 的双螺旋结构对反应也起到一定的促进作用.
\end{abstract}

关键词 双链 DNA; 鲱鱼精; 催化; 二硫缩醛; 水相; 磷酸基团

DNA Catalyzed Dithioacetalization in Water
Wang, Changhao Li, Yinghao Jia, Guoqing Lu, Shengmei Liu, Yan Li, Can*
(State Key Laboratory of Catalysis, Dalian Institute of Chemical Physics,
Chinese Academy of Sciences, Dalian 116023, China)

\section{Introduction}

Dithioacetalization of carbonyl compounds is a common practice in organic synthesis, which is usually catalyzed by strong protic or Lewis acids. ${ }^{[1-7]}$ The products in the form of 1,3-dithiolanes are often serving as protecting groups, precursors of acyl anions and masked methylene functions in carbon-carbon bond forming reactions. ${ }^{[8-10]}$ Unfortunately, many of the existing methods have drawbacks such as using toxic organic solvents, stoichiometric amounts of catalysts and drastic reaction conditions. For this reaction, using water as a reaction solvent has particularly received a great deal of attention, ${ }^{[11-14]}$ because water is not only a cheap, safe, and environmentally benign solvent, but also possibly helpful for improving the performances of the catalytic reactions. ${ }^{[15-20]}$ To date, dithioacetalizations in water media were reported by $\mathrm{InBr}_{3},{ }^{[21]}$ dodecylbenzenesulfonic acid, ${ }^{[22,23]}$ sulfonic acid/ $\mathrm{SiO}_{2},{ }^{[24]}$ copper bis(dode- cylsulfate), ${ }^{[25]} \mathrm{I}_{2} / \mathrm{Al}_{2} \mathrm{O}_{3}{ }^{[26]}$ and trichloroacetic acid/sodium dodecylsulfate $^{[27]}$ as the catalysts.

In the presumed "RNA World", RNA is proposed to be the origin of cellular life, which acts as genes like DNA

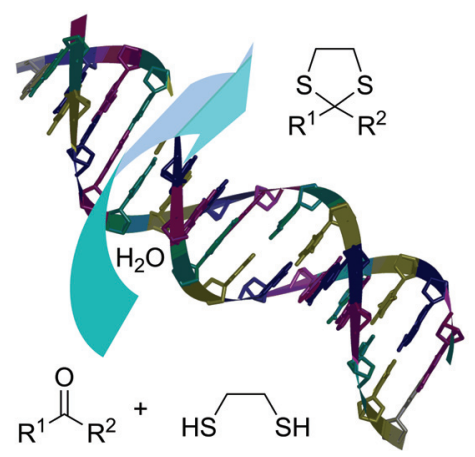

Scheme 1 DNA catalyzed dithioacetalization in water

* E-mail: canli@dicp.ac.cn; Tel.: 0086-0411-84379070; Fax: 0086-0411-84694447

Received December 22, 2012; published January 8, 2013.

Supporting information for this article is available free of charge via the Internet at http://sioc-journal.cn

Project supported by the National Natural Science Foundation of China (Nos. 20773123, 20621063, 31000392).

项目受国家自然科学基金(Nos. 20773123, 20621063, 31000392)资助. 
and enzymes like proteins. ${ }^{[28-33]}$ Since RNA was discovered to be not only a genetic material but also a catalytic species in nature, ${ }^{[34,35]}$ it has been inevitable to speculate whether DNA possesses the catalytic function. Double-stranded DNA is commonly regarded as a carrier of genetic information in living organisms. Although the biological understanding of DNA is extensively exploited, DNA for nonbiological applications arouses much interest to chemists in chemical synthesis, e.g. DNA-templated organic synthesis $^{[36,37]}$ and DNA-based asymmetric catalysis. ${ }^{38-40]}$ Since DNA is chemically stable and commercially available, there are some reported examples of the Henry, Aldol and Michael reactions using natural duplex DNA as a catalyst. $^{[41-43]}$ Very recently, human telomeric G-quadruplex DNA is reported to show enantioselective catalytic function. ${ }^{[44,45]}$ However, the investigation of DNA as a direct catalyst for organic synthesis is still an open question. Herein, we report that double-stranded DNA from herring sperm (hsDNA) can catalyze the dithioacetalization in water for a wide range of aldehydes under mild condition (Scheme 1). It is proposed that the phosphate groups of DNA together with its duplex structure are responsible for the catalytic reaction.

\section{Results and discussion}

\subsection{Dithioacetalization in water using DNA as a cata- lyst}

As an initial attempt, the dithioacetalization of benzaldehyde and 1,2-ethanedithiol in water was selected as a model reaction to test the catalytic performance of hsDNA. In the absence of hsDNA, the benzaldehyde was transferred to 2-phenyl-1,3-dithiolane at a very low yield at 3\% (Table 1, Entry 1) at $310 \mathrm{~K}$ for 12 hours. After a small amount of hsDNA ( $5 \mathrm{mg}$ ) was added, the yield is increased to $16 \%$ (Table 1, Entry 2), which suggests that DNA may play a catalytic role in the dithioacetalization. The dithioacetalization of benzaldehyde and 1,2-ethanedithiol in the presence of hsDNA proceeded cleanly with 2-phenyl-

Table 1 Dithioacetalization of benzaldehyde with 1,2-ethanedithiol in the presence of hsDNA

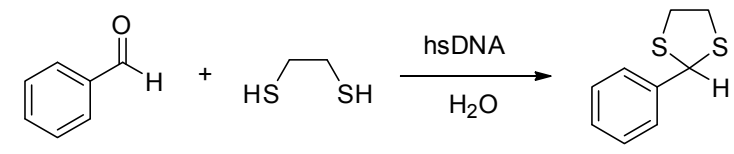

\begin{tabular}{cccc}
\hline Entry $^{a}$ & hsDNA/mg & $T / \mathrm{K}$ & $\mathrm{GC} \mathrm{yield}^{b} \%$ \\
\hline 1 & 0 & 310 & 3 \\
2 & 5 & 310 & 16 \\
3 & 10 & 310 & 39 \\
4 & 20 & 310 & 55 \\
5 & 30 & 310 & 67 \\
$6^{c}$ & 40 & 310 & 72 \\
$7^{d}$ & 30 & 310 & 82 \\
8 & 30 & 323 & 90 \\
9 & 30 & 333 & 94 \\
10 & 30 & 343 & 95 \\
11 & 30 & 353 & $>99$ \\
\hline${ }^{a}$ Reaction conditions: benzaldehyde & $(0.25 \mathrm{mmol})$, 1,2-ethanedithiol $(0.5$
\end{tabular}
mmol), hsDNA, $\mathrm{H}_{2} \mathrm{O}(2 \mathrm{~mL}), 12 \mathrm{~h} .{ }^{b}$ Determined by GC averaged by two experiments with the reproducibility within $\pm 3 \%{ }^{c} 40 \mathrm{mg}$ hsDNA can not be completely dissolved in $2 \mathrm{~mL} \mathrm{H}_{2} \mathrm{O} .{ }^{d} 24 \mathrm{~h}$ reaction time. 1,3-dithiolane as the sole product and no by-product was observed on the GC traces (see supporting information). With increasing the amount of hsDNA, the yield of the dithioacetalization is increasing nearly proportionally (Table 1, Entries 3-5). However, hsDNA is not completely dissolved when the DNA $/ \mathrm{H}_{2} \mathrm{O}$ ratio reaches $20 \mathrm{mg} / \mathrm{mL}$ (Table 1, Entry 6). The reactivity of the dithioacetalization can be improved slightly with prolonging the reaction time (Table 1, Entry 5 vs. Entry 7). Furthermore, the effect of the reaction temperature was also investigated for the dithioacetalization in the presence of DNA. Compared with the dithioacetalization at $310 \mathrm{~K}$, the yield reaches $90 \%$ when the reaction is conducted at $323 \mathrm{~K}$ (Table 1, Entry 8 vs. Entry 5). Continue increasing the reaction temperature, both the reactivity of the DNA-catalyzed dithioacetalization and the corresponding background reaction are reasonably enhanced (Table 1, Entries 9-11 and Table S1), but the contribution from the background reaction is becoming more. According to the above results, it is obvious that DNA could function as a catalyst in the dithioacetalization.

\subsection{Active species of DNA in the dithioacetalization}

To illustrate the catalytic function of DNA, it is necessary to determine the activation energy for the dithioacetalization in the absence or presence of DNA. The initial rates $\left(V_{\text {init. }}\right)$ of the dithioacetalization at different reaction temperatures were measured in Table S2. The activation energy $\left(E_{\mathrm{a}}\right)$ is derived from the Arrhenius plots of the natural logarithm of the $V_{\text {init. }}$ vs. $1 / T$ for the dithioacetalization (Figure 1). In the absence of DNA, $E_{\text {a,uncat }}$ is estimated to be $76.3 \mathrm{~kJ} / \mathrm{mol}$. While in the presence of DNA, $E_{\mathrm{a}, \mathrm{cat}}$ is estimated to be $18.3 \mathrm{~kJ} / \mathrm{mol}$. The considerable decrease in the activation energy $\left(\Delta E_{\mathrm{a}}=E_{\mathrm{a} \text {,uncat. }}-E_{\mathrm{a} \text {,cat. }}=58.0 \mathrm{~kJ} / \mathrm{mol}\right)$ using DNA confirms that DNA acts as a catalyst in the dithioacetalization.

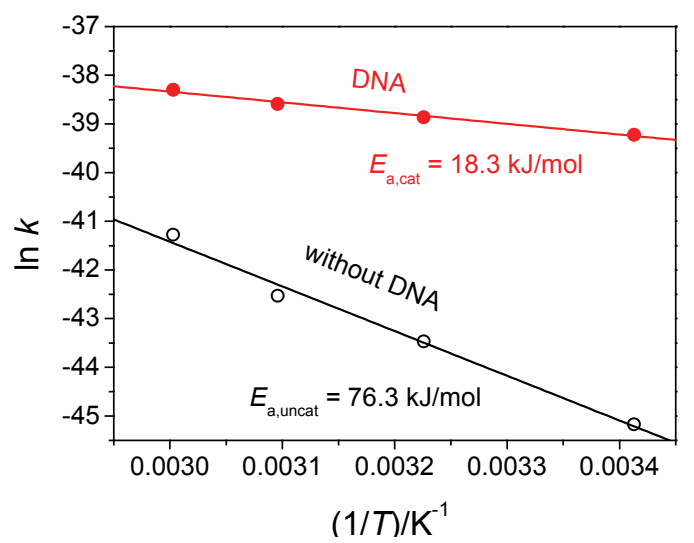

Figure 1 Arrhenius plots for the dithioacetalization in the absence (O) and presence $(\bullet)$ of hsDNA. The initial rate $\left(V_{\text {init. }}\right)$ of the dithioacetalization between benzaldehyde and 1,2-ethanedithiol is calculated during the first $30 \%$ of the reaction in the temperature range of $293-333 \mathrm{~K}$.

To rationalize the catalytic role of DNA for the dithioacetalization, a series of control experiments with various amount of DNA were conducted for the dithioacetalization between benzaldehyde and 1,2-ethanedithiol in aqueous media at $323 \mathrm{~K}$. As shown in Table 2, the reactivity of the dithioacetalization at $323 \mathrm{~K}$ in $\mathrm{H}_{2} \mathrm{O}$ is enhanced with in- 
creasing the amount of hsDNA (Table 2). However, the $\mathrm{pH}$ value of the reaction medium is detected to be decreased after the addition of hsDNA (Table 2). In order to rule out the influence of the $\mathrm{pH}$ value, we carried out the benchmark reaction using a phosphate buffer $\left(\mathrm{Na}_{2} \mathrm{HPO}_{4}\right.$-Citric acid) and a non-phosphate buffer (Potassium biphthalate- $\mathrm{HCl}$ ). Using a phosphate buffer at $\mathrm{pH} 2.3$ as the reaction medium, compared to the reaction without hsDNA (67\%, Table 2, Entry 1), the reactivity of the dithioacetalization is slightly improved at a constant $\mathrm{pH}$ value when the amount of hsDNA is increasing (Table 2, Entries 2 and 3). When the amount of DNA reaches $30 \mathrm{mg}$, the yield is up to $84 \%$ (Table 2, Entry 4). Continue increasing the amount of DNA, the yield can not be significantly changed (Table 2, Entry 5). The similar trend was obtained when using a non-phosphate buffer (Table 2). Taken together, these above results suggest that DNA really shows catalytic function for the dithioacetalization.

To further identify the active species of DNA, we carried out the control experiments in aqueous media with the component of DNA as a catalyst (Table 3). Using $\mathrm{H}_{2} \mathrm{O}$ as the reaction medium, we firstly ran the dithioacetalization in the presence of various salts to rule out the salt effect

Table 2 Control experiments of benzaldehyde and 1,2-ethanedithiol with various amount of hsDNA in different reaction media

\begin{tabular}{ccccc}
\hline & \multirow{4}{*}{ Entry $^{a} \begin{array}{c}\text { hC yield }^{b} / \% \\
/ \mathrm{mg}\end{array}$} & $\begin{array}{c}\mathrm{H}_{2} \mathrm{O} \\
(\mathrm{pH} \text { value })^{c}\end{array}$ & $\begin{array}{c}\text { Phosphate buffer } \\
(\mathrm{pH}=2.3)^{d}\end{array}$ & $\begin{array}{c}\text { Non-phosphate buffer } \\
(\mathrm{pH}=2.3)^{e}\end{array}$ \\
\hline 1 & 0 & $17(6.5)$ & 67 & 56 \\
2 & 10 & $57(3.3)$ & 73 & 64 \\
3 & 20 & $77(2.8)$ & 78 & 71 \\
4 & 30 & $90(2.3)$ & 84 & 83 \\
5 & 40 & $90(2.2)$ & 85 & 84 \\
\hline
\end{tabular}

a Reaction conditions: benzaldehyde $(0.25 \mathrm{mmol})$, 1,2-ethanedithiol $(0.5$ mmol), hsDNA, reaction media $(2 \mathrm{~mL}), 323 \mathrm{~K}, 12 \mathrm{~h} .{ }^{b}$ Determined by GC averaged by two experiments with the reproducibility of $\pm 3 \%{ }^{c}{ }^{c} \mathrm{pH}$ values were detected after hsDNA was added. ${ }^{d} \mathrm{Na}_{2} \mathrm{HPO}_{4}(0.2 \mathrm{~mol} / \mathrm{L})$-Citric acid $(0.1$ $\mathrm{mol} / \mathrm{L})$ buffer. ${ }^{e}$ Potassium biphthalate $(0.2 \mathrm{~mol} / \mathrm{L})-\mathrm{HCl}(0.2 \mathrm{~mol} / \mathrm{L})$ buffer.

Table 3 Control experiments of benzaldehyde and 1,2-ethanedithiol in aqueous media

\begin{tabular}{cccc}
\hline & & \multicolumn{2}{c}{ GC yield $^{b} \%$} \\
\cline { 3 - 4 } Entry $^{a}$ & Catalyst & $\begin{array}{c}\mathrm{H}_{2} \mathrm{O} \\
(\mathrm{pH} \text { value })^{c}\end{array}$ & $\begin{array}{r}\text { Phosphate buffer } \\
(\mathrm{pH}=2.3)^{d}\end{array}$ \\
\hline 1 & none & $17(6.5)$ & 67 \\
2 & $\mathrm{NaCl}$ & $17(6.5)$ & 64 \\
3 & $\mathrm{MgCl}_{2}$ & $19(6.5)$ & 70 \\
4 & Thymine & $12(6.5)$ & 68 \\
5 & Guanine & $15(6.5)$ & 46 \\
6 & Adenine & $<1(6.5)$ & 66 \\
7 & Cytosine & $<1(6.8)$ & 72 \\
8 & dTMP & $44(2.7)$ & 73 \\
9 & dGMP & $48(2.8)$ & 67 \\
10 & dAMP & $61(2.8)$ & 66 \\
11 & dCMP & $45(2.7)$ & 84 \\
12 & hsDNA & $90(2.3)$ & 79 \\
13 & ctDNA & $86(2.1)$ & $>99$ \\
14 & DPP & $>99(1.5)$ & 69 \\
\hline
\end{tabular}

a Reaction conditions: benzaldehyde $(0.25 \mathrm{mmol})$, 1,2-ethanedithiol $(0.5$ $\mathrm{mmol}$ ), catalyst $(30 \mathrm{~mol} \%)$, reaction media $(2 \mathrm{~mL}), 323 \mathrm{~K}, 12 \mathrm{~h} .{ }^{b}$ Determined by GC averaged by two experiments with the reproducibility within $\pm 3 \%$. ${ }^{c} \mathrm{pH}$ values were detected after hsDNA was added. ${ }^{d} \mathrm{Na}_{2} \mathrm{HPO}_{4}(0.2 \mathrm{~mol} / \mathrm{L})$-Citric acid $(0.1 \mathrm{M})$ buffer. ${ }^{e}$ Calf thymus DNA. ${ }^{f}$ Diphenyl phosphate.

compared with the reaction without catalyst (Table 3, En- tries 2,3 vs. Entry 1). The use of four nucleobases of DNA as catalysts performs poor in the dithioacetalization (Table 3, Entries 4-7). Different deoxyribonucleotides of DNA i.e. dTMP, dGMP, dAMP and dCMP were investigated to obtain the modest yields yet the $\mathrm{pH}$ values of the reaction medium are changing from 6.5 to about 2.7 (Table 3, Entries $8-11$ ), leading us to propose that phosphate groups of DNA provides protons to achieve the reaction. In the presence of DNA such as hsDNA and calf thymus DNA (ctDNA), the reaction media become more acidic than those of the deoxyribonucleotides, thus higher yields were obtained (Table 3, Entries 12 and 13). A simple phosphate such as diphenyl phosphate (DPP) was tested and a quantitative conversion was obtained (Table 3, Entry 14). Bases on the above results, it seems that phosphate group of DNA is the catalytic species. However, when we investigated the $\mathrm{pH}$ effect to the dithioacetalization (Table S3), the results show that the presence of DNA performs better than that of no catalyst at a constant $\mathrm{pH}$ value in a phosphate buffer, although the proton concentration is demonstrated to be the key factor. Therefore, we deduced that the phosphate groups of DNA may not be the only active species. To exclude the $\mathrm{pH}$ effect, we employed a phosphate buffer $\left(\mathrm{Na}_{2} \mathrm{HPO}_{4}\right.$-Citric acid, $\left.\mathrm{pH} 2.3\right)$ as the reaction medium instead of pure water. Without catalyst, the protons in the phosphate buffer promoted the reaction to provide a $67 \%$ yield (Table 3, Entry 1). The salt effect is ruled out in a phosphate buffer compared to the background reaction (Table 3, Entries 2,3 vs. Entry 1). Nucleobases and deoxyribonucleotides were screened to find that they are not efficient catalysts in a phosphate buffer (Table 3, Entries $4-11$ ). Compared to the background reaction at $\mathrm{pH}=2.3$, the dithioacetalization in phosphate buffer by hsDNA exhibits little higher activity (Table 3, Entry 12 vs. Entry 1) and similar result was obtained as represented by ctDNA (Table 3, Entry 13 vs. Entry 1). Although the difference is not significantly high, it suggests that architecture of double-stranded DNA might be also responsible for the catalytic performance in the dithioacetalization besides the main catalytic species of the phosphate groups. We speculate that both substrates might be involved in simultaneous binding to the major groove of DNA, thus enhancing the local effective concentrations of the reactants. The above control experiments were also investigated in a non-phosphate buffer and similar trends were obtained as those in the phosphate buffer (Table S4).

\subsection{Substrate scope of the dithioacetalization by DNA}

In order to demonstrate the catalytic function of DNA for the dithioacetalization, DNA was tested for the dithioacetalization in water with a broad scope of substrates (Table 4). Several aromatic and aliphatic aldehydes with both electron-withdrawing and donating substituents produced the desired dithioacetals in modest to excellent yields (Table 4, Entries 1-8). Compared to benzaldehyde as a substrate (90\%; Table 4, Entry 1), p-methoxybenzaldehyde with a strong electron-donating substituent provides little higher yield at $94 \%$ of the corresponding product (Table 4 , Entry 2). However, $p$-methylbenzaldehyde provides the corresponding dithioacetal at a relatively lower yield at $78 \%$ (Table 4, Entry 3). When the aromatic aldehydes bearing electron-withdrawing substituents such as $p$-fluoro 
and $p$-trifluoromethyl, the corresponding dithioacetalizations both provide lower yields than that of benzaldehyde (Table 4, Entries 4, 5 vs. Entry 1). The aldehyde with a bulk aromatic substitute (1-naphthyl) shows much lower activity compared with benzaldehyde (Table 4, Entry 6 vs. Entry 1), implying that a bulk substitute may block the interaction between substrate and DNA. $\alpha, \beta$-Unsaturated aromatic aldehyde such as cinnamaldehyde gives an excellent yield of $97 \%$ (Table 4, Entry 7). The above results show that the reactivity of aromatic aldehydes in DNA-catalyzed dithioacetalization reaction is strongly affected by the electronic and steric effects. Aliphatic aldehyde such as $n$-butanal provides $89 \%$ yield in the corresponding DNA-catalyzed dithioacetalization (Table 4, Entry 8). In addition, aliphatic ketone such as cyclohexanone was tested and a modest yield of the corresponding dithioacetal was obtained (Table 4, Entry 9).

Table 4 Substrate scope for the DNA-catalyzed dithioacetalization in water

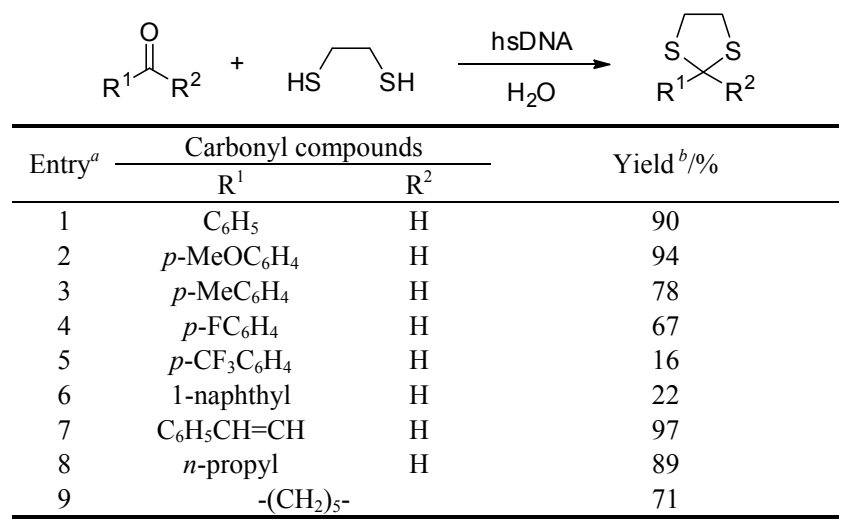

${ }^{a}$ Reaction conditions: carbonyl compound $(0.25 \mathrm{mmol}), 1,2$-ethanedithiol $(0.5$ mmol), hsDNA (30 mg, $30 \mathrm{~mol} \%), \mathrm{H}_{2} \mathrm{O}(2 \mathrm{~mL}), 323 \mathrm{~K}, 12 \mathrm{~h}$. All data are averaged by two experiments. ${ }^{b}$ Determined by GC yield of the product of benzaldehyde with the reproducibility of $\pm 3 \%$ and isolated yields of others with the reproducibility of $\pm 5 \%$.

\section{Conclusions}

In summary, we found that natural double-stranded DNA can catalyze the dithioacetalization to dithioacetals in water under mild reaction conditions. We proposed that phosphate groups of DNA together with its duplex architecture are responsible for the catalytic performance. This work offers a protocol to the synthesis of dithioacetals in water using DNA through a simple procedure under mild conditions. Although this reaction may have little or no relevant to life process, it is helpful for us to understand the catalytic function of DNA which might shed light on the possible catalytic reactions of DNA in biological systems.

\section{Acknowledgements}

We thank Prof. Zhaochi Feng, Prof. Qihua Yang, Dr. Jun Li, Dr. Jun Zhou and Dr. Peng Liu of Dalian Institute of Chemical Physics, Chinese Academy of Sciences, for their helpful discussions.

\section{References}

[1] Ralls, J. W.; Dodson, R. M.; Riegel, B. J. Am. Chem. Soc. 1949, 71, 3320.

[2] Djerassi, C.; Gorman, M. J. Am. Chem. Soc. 1953, 75, 3704.

[3] Aoyama, T.; Takido, T.; Kodomari, M. Synlett 2004, 2307.

[4] Tani, H.; Masumoto, K.; Inamasu, T.; Suzuki, H. Tetrahedron Lett. 1991, 32, 2039.

[5] Firouzabadi, H.; Karimi, B.; Eslami, S. Tetrahedron Lett. 1999, 40, 4055.

[6] Moghaddam, F. M.; Bardajee, G. R.; Oskui, A. A. Phosphorus, Sulfur Silicon Relat. Elem. 2006, 181, 1445.

[7] Shaterian, H. R.; Hosseinian, A.; Ghashang, M. Synth. Commun. 2008, 38, 4097 .

[8] Corey, E. J.; Seebach, D. Angew. Chem. Int. Ed. Engl. 1965, 4, 1075.

[9] Seebach, D. Angew. Chem. Int. Ed. Engl. 1969, 8, 639.

[10] Seebach, D. Angew. Chem. Int. Ed. Engl. 1979, 18, 239.

[11] Li, C. J. Chem. Rev. 2005, 105, 3095.

[12] Chanda, A.; Fokin, V. V. Chem. Rev. 2009, 109, 725.

[13] Butler, R. N.; Coyne, A. G. Chem. Rev. 2010, 110, 6302.

[14] Simon, M.-O.; Li, C.-J. Chem. Soc. Rev. 2012, 41, 1415.

[15] Otto, S.; Bertoncin, F.; Engberts, J. J. Am. Chem. Soc. 1996, 118 , 7702 .

[16] Li, H. J.; Zhao, J. L.; Chen, Y. J.; Liu, L.; Wang, D.; Li, C. J. Green Chem. 2005, 7, 61 .

[17] Fousteris, M.; Chevrin, C.; Le Bras, J.; Muzart, J. Green Chem. 2006, 8, 522 .

[18] Guizzetti, S.; Benaglia, M.; Raimondi, L.; Celentano, G. Org. Lett. 2007, 9, 1247.

[19] Tandon, V. K.; Maurya, H. K. Tetrahedron Lett. 2010, 51, 3843.

[20] Landelle, G.; Claraz, A.; Oudeyer, S.; Levacher, V. Tetrahedron Lett. 2012, 53, 2414

[21] Ceschi, M. A.; Felix, L. D.; Peppe, C. Tetrahedron Lett. 2000, 41, 9695.

[22] Manabe, K.; Iimura, S.; Sun, X. M.; Kobayashi, S. J. Am. Chem. Soc. 2002, 124, 11971.

[23] Dong, D. W.; Yan, O. Y.; Yu, H. F.; Liu, Q.; Liu, J.; Wang, M.; Zhu, J. J. Org. Chem. 2005, 70, 4535 .

[24] Karimi, B.; Khalkhali, M. J. Mol. Catal. A: Chem. 2007, 271, 75.

[25] Weng, S.-S.; Chang, S.-C.; Chang, T.-H.; Chyn, J.-P.; Lee, S.-W.; Lin, C.-A.; Chen, F.-K. Synthesis 2010, 1493.

[26] Rohman, M. R.; Rajbangshi, M.; Laloo, B. M.; Sahu, P. R.; Myrboh, B. Tetrahedron Lett. 2010, 51, 2862

[27] Bahrami, K.; Khodaei, M. M.; Tajik, M.; Soheilizad, M. J. Sulfur Chem. 2011, 32, 397.

[28] Robertson, M. P.; Joyce, G. F. Cold Spring Harb. Perspect. Biol. 2012, 4, 1.

[29] Bada, J. L.; Lazcano, A. Science 2002, 296, 1982.

[30] Poole, A. M.; Jeffares, D. C.; Penny, D. J. Mol. Evol. 1998, 46, 1.

[31] Lorsch, J. R.; Szostak, J. W. Acc. Chem. Res. 1996, 29, 103.

[32] Gilbert, W. Nature 1986, 319, 618.

[33] Pace, N. R.; Marsh, T. L. Origins Life Evol. Biosphere 1985, 16, 97.

[34] Kruger, K.; Grabowski, P. J.; Zaug, A. J.; Sands, J.; Gottschling, D. E.; Cech, T. R. Cell 1982, 31, 147.

[35] Guerriertakada, C.; Gardiner, K.; Marsh, T.; Pace, N.; Altman, S. Cell 1983, 35, 849.

[36] Li, X. Y.; Liu, D. R. Angew. Chem. Int. Ed. 2004, 43, 4848.

[37] Silverman, A. P.; Kool, E. T. Chem. Rev. 2006, 106, 3775.

[38] Roelfes, G.; Feringa, B. L. Angew. Chem. Int. Ed. 2005, 44, 3230.

[39] Boersma, A. J.; Megens, R. P.; Feringa, B. L.; Roelfes, G. Chem. Soc. Rev. 2010, 39, 2083.

[40] Silverman, S. K. Angew. Chem. Int. Ed. 2010, 49, 7180.

[41] Fan, J.; Sun, G.; Wan, C.; Wang, Z.; Li, Y. Chem. Commun. 2008, 3792.

[42] Sun, G.; Fan, J.; Wang, Z.; Li, Y. Synlett 2008, 2491.

[43] De Rosa, M.; Di Marino, S.; D'Ursi, A. M.; Strianese, M.; Soriente, A. Tetrahedron 2012, 68, 3086.

[44] Wang, C.; Jia, G.; Zhou, J.; Li, Y.; Liu, Y.; Lu, S.; Li, C. Angew. Chem. Int. Ed. 2012, 51, 9352.

[45] Wang, C.; Li, Y.; Jia, G.; Liu, Y.; Lu, S.; Li, C. Chem. Commun. 2012, 48, 6232 . 